\title{
突合せ溶接継手における軸方向亀裂の進展予測手順 (半円より深い亀裂や溶接境界部での停留する亀裂の進展予測)
}

\section{An axial crack growth prediction procedure initiated at butt welded joint (Growth prediction for surface crack deeper than semi-circular and that retarded at weld fusion line)}

\author{
Masayuki KAMAYA*1 \\ ${ }^{* 1}$ Institute of Nuclear Safety System, Inc. \\ 64 Sata, Mihama-cho, Mikata-gun, Fukui 919-1205 Japan
}

Received: 15 October 2017; Revised: 19 December 2017; Accepted: 28 January 2018

\begin{abstract}
Structural integrity of cracked pipes is assessed by predicting crack growth. In the fitness-for-service code of the Japan Society of Mechanical Engineers (JSME), the crack growth is predicted using stress intensity factor at the deepest and surface points. A semi-elliptical crack is assumed not to become deeper than a semi-circular crack. However, in reality, the stress corrosion cracking initiated at nickel alloy welds stops growing at the fusion line and becomes deeper than a semi-circular crack. Furthermore, crack shape is close to a rectangular shape rather than a semi-elliptical shape. In this study, validity of the JSME code procedure was discussed for predicting the growth of stress corrosion cracking at nickel alloy welds. Crack growth was simulated by finite element analysis together with an auto meshing technique. Various residual stress distributions and retardation of the crack growth at the fusion line were considered in the simulation. It was demonstrated that the growth prediction procedure prescribed in the JSME code brought about a conservative prediction even if the crack became deeper than the depth of a semi-circular shape crack. It was revealed that, when the growth to the surface direction was retarded at the fusion line, the change in crack size in the depth direction could be predicted conservatively by the current JSME procedure. It was suggested that, when the retardation at the fusion line is assumed in the growth prediction, the crack shape should be modelled by a rectangular shape.
\end{abstract}

Keywords : Fittness-for-service, Crack growth, PWSCC, Nickel based alloy, Weld, Automeshing technique, Nuclear power plant

\section{1. 緒言}

日本機械学会の発電用設備規格維持規格（日本機械学会, 2016）（以後, 維持規格）における亀裂進展予測では, 実際の亀裂形状を半円または半楕円（以後，まとめて半楕円と表記する）にモデル化するよう規定している．そ して，表面点と最深点の 2 点における応力拡大係数（K 值）から，表面方向と深さ方向それぞれの進展量を算出 し，半楕円形状を維持させながら進展予測を行う．その際，亀裂のアスペクト比（深さ $\times 2 /$ 表面長さ）は，半円 形状に相当する 1 を超えないように制限している．深さ方向の進展が表面方向よりも速く，アスペクト比が 1 を 超える場合は，表面長さを大きくしてアスペクト比が 1 の半円形状に置き換える. アスペクト比を 1 以下に制限 する理由として，曲げや引張りなどの応力に対する進展ではアスペクト比が 1 を超えるような成長は考えられな いこと，一般的な K 值解はアスペクト比が 1 以下のものを対象にしていることが考えられる.

残留応力下での応力腐食割れ（SCC）による亀裂進展では, 残留応力分布によってはアスペクト比が 1 を超え ることも考えられる．また，亀裂成長速度の材料依存性によってもアスペクト比が 1 を超える場合もある. 図 1

No.17-00457 [DOI:10.1299/transjsme.17-00457], J-STAGE Advance Publication date : 6 February, 2018

*1 正員, (株) 原子力安全システム研究所（广919-1205＼cjkstart福井県三方郡美浜町佐田 64）

E-mail of corresponding author: kamaya@inss.co.jp 

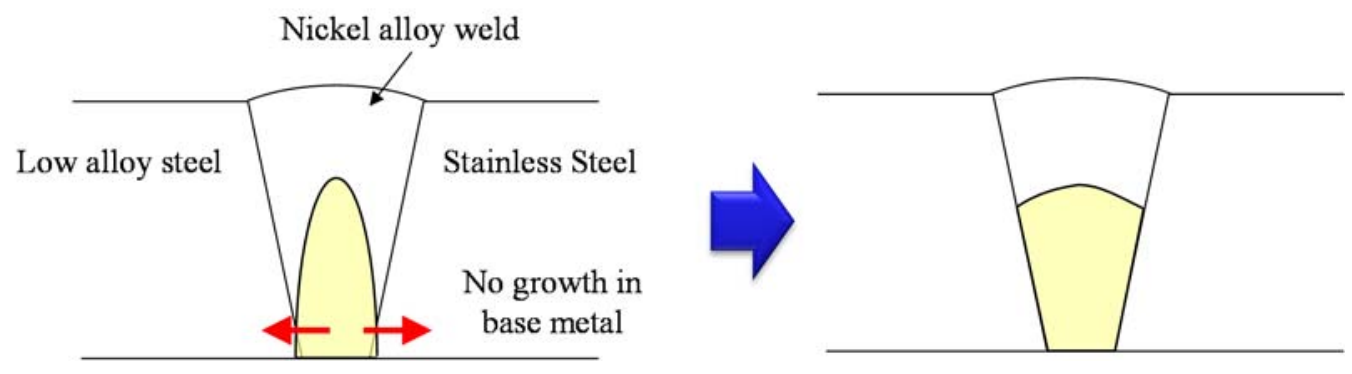

Fig. 1 A schematic drawing representing crack growth behavior of stress corrosion crack initiated at Nickel weld. The crack is difficult to go into low alloy steel and stainless steel.

に示すように，原子力発電プラントでは，低合金鋼とステンレス鋼の継手部は，ニッケル合金によって溶接され る. 加圧水型原子炉の一次系環境下では, ニッケル合金に SCC が発生することが知られているが, 低合金鋼やス テンレス鋼では, SCC が発生・進展しない，または，発生・進展しにくい，したがって，ニッケル合金で発生し た SCC は，亀裂先端が低合金鋼または，ステンレス鋼まで進展すると，図 1 に示すように進展が停止すると予想 される. 結果として，アスペクト比が 1 を超える亀裂形状になる. アスペクト比を 1 以下に制限している現状の 維持規格の評価手順が，このような進展に対しても問題なく適用できる（安全側に予測できる）ことを確認して おく必要がある。一方，検査間隔の設定や，亀裂が実際に発見された場合の原因究明のためには，安全側の予測 ではなく, 現実に近い予測も求められる. 図 1 に示すような亀裂進展挙動を模擬するためには, 亀裂形状を半楕 円ではなく矩形などでモデル化する方法も考えられる.

本報では, 図 1 のような突合せ溶接継手において発生した軸方向のSCC の進展予測を行う場合に, 現状の維持 規格の手順が妥当であることの検証と，より合理的な予測を行うための手順の検討を行った. 亀裂形状や応力分 布に依存して亀裂前縁の位置によって K 值が変化する. 本報では, 亀裂前縁の各位置での $\mathrm{K}$ 值に対応した進展を 模擬することで実際の進展挙動を再現できると仮定する.これに対し, 亀裂形状を半楕円や矩形にモデル化した り, 表面点と最深点の $\mathrm{K}$ 值のみを用いて進展予測を行ったりする予測手順が，どの程度実際の進展挙動を模擬で きるかを調べる．実際の進展挙動の再現解析と半楕円亀裂の進展解析には自動メッシュ亀裂進展解析コード FECRACK (Kamaya, 2006) を用いた. このコードでは, 任意の亀裂形状に対応する有限要素メッシュの自動作成と, Abaqusによる有限要素解析を行う. また, 亀裂を矩形でモデル化する場合の進展解析には, 矩形亀裂のメッシュ を自動生成する RECT-CRACK（Kamaya, 2009）を適用した.

\section{2. 解析方法}

\section{$2 \cdot 1$ 概要}

亀裂前縁の $\mathrm{K}$ 值を有限要素解析で算出し, 進展速度を予測することで亀裂進展を模擬した. 有限要素解析で $\mathrm{K}$ 值は亀裂前縁上の各節点で算出される，そのため，亀裂前縁の位置によって亀裂成長量が異なり，半楕円形状の 亀裂であっても成長後の形状が必ずしも半楕円になるとは限らない，一様な引張りや曲げ荷重のように単純な荷 重が負荷される場合, 亀裂形状は半楕円形状で近似できる (Kamaya, 2008). しかし, 残留応力のような複雑な応 力分布の場合は, 亀裂の前縁の位置によって作用する応力が変化し, 亀裂形状が半楕円形状から逸脱する可能性 がある．FE-CRACK は，指定した亀裂形状に対して有限要素メッシュ分割を自動的に行う機能を有している

(Kamaya, 2006)。一方, RECT-CRACK では, 矩形の亀裂形状を維持しながら, 亀裂の成長に応じてメッシュ分 割を自動的に行う（Kamaya, 2009）。いずれのソフトウェアでも, 亀裂進展量の算出に必要な K 值を Abaqusによ る有限要素解析により求める.

図 2 に示すような, 平板に存在する表面亀裂を対象とした. 平板の厚さ $t$ は $70 \mathrm{~mm}$ とし, 幅 $W$, 長さ $B$ は $4 t$ と した，対称性を考慮し $1 / 4$ モデルを, 図 3 に示すようにメッシュ分割した. メッシュ分割に対する妥当性は FECRACK については文献（Kamaya, 2006），RECT-CRACKについては文献（Kamaya, 2009）で検証されている. 


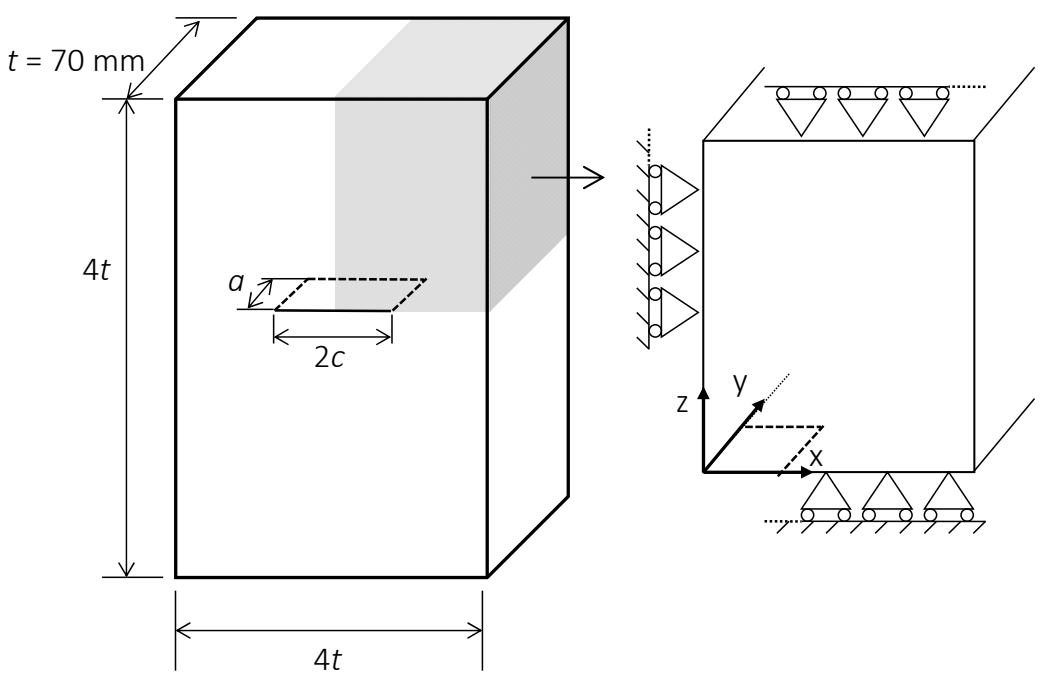

Fig.2 Cracked plate model for crack growth simulation. The stress intensity factor was calculated by finite element model with the boundary conditions shown in this figure.

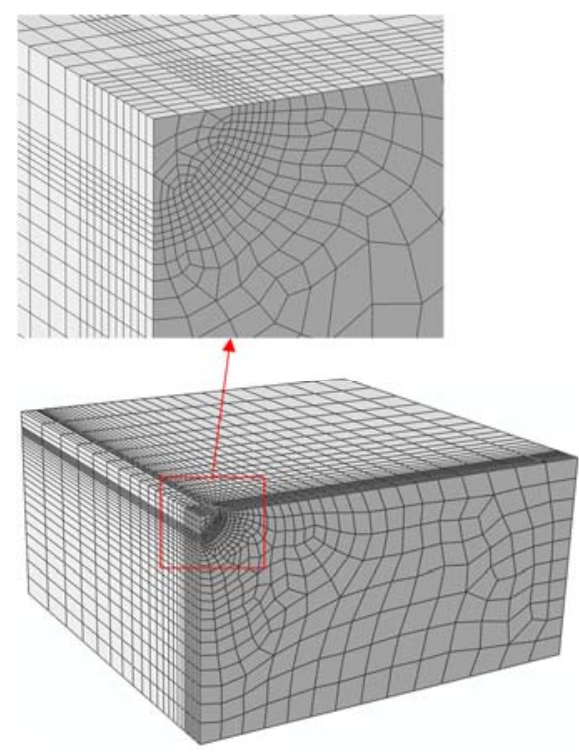

(a)FE-CRACK

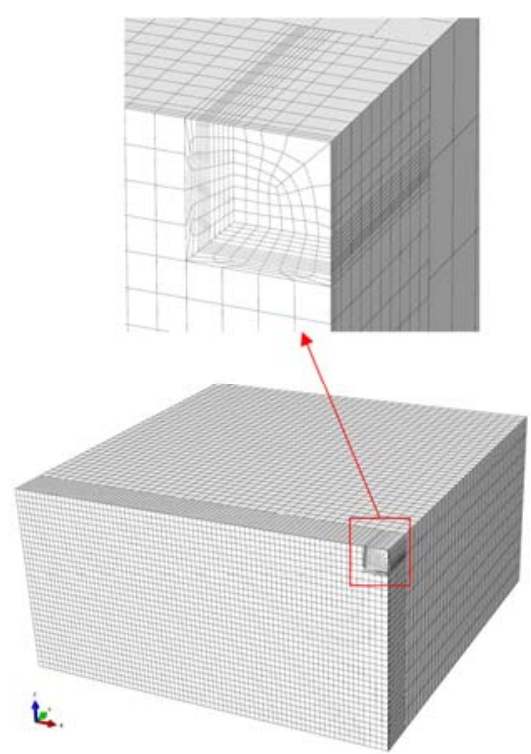

(b)RECT-CRACK

Fig.3 Typical finite element meshes used for crack growth simulations ( $a=c=7 \mathrm{~mm}, t=70 \mathrm{~mm}, W=140 \mathrm{~mm}, B=140 \mathrm{~mm}$ ).

\section{$2 \cdot 2$ 解析条件}

亀裂形状は, 図 2 で示すように, 深さを $a$, 長さを $2 c$ で定義する. ヤング率は $180 \mathrm{GPa}$, ポアソン比は 0.3 の 弾性材料を想定した.

一次冷却材管のニッケル合金溶接部での残留応力 $\sigma_{\mathrm{RS}}$ として, 以下の 3 種類の分布を仮定した（図 4 参照).

$$
\begin{aligned}
& \sigma_{\mathrm{RS}(\mathrm{ASME})}[\mathrm{MPa}]=330 \frac{y}{t}+50 \\
& \sigma_{\mathrm{RS}(\mathrm{JPN})}[\mathrm{MPa}]=-9850.8\left(\frac{y}{t}\right)^{4}+17887.9\left(\frac{y}{t}\right)^{3}-8996.4\left(\frac{y}{t}\right)^{2}+1167.8\left(\frac{y}{t}\right)+134.1 \\
& \sigma_{\mathrm{RS}(\mathrm{UNI})}[\mathrm{MPa}]=50
\end{aligned}
$$




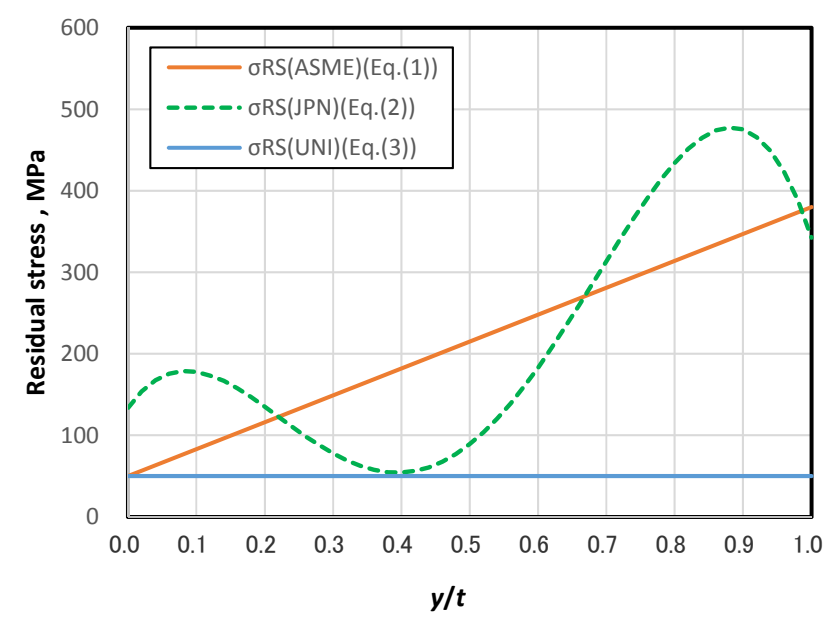

Fig. 4 Residual stresses in the circumferential direction assumed in the crack growth simulations.

ここで，yは表面から亀裂深さ方向の距離を示す. 式（1）は，米国機械学会で提案されている周方向応力分布と なっている (Broussard, 2015)（以後, $\sigma_{\mathrm{RS}(\mathrm{ASME})}$ と表記する).この式は, 容器ノズル部のニッケル合金溶接部の SCC 亀裂進展を予測するための代表的な值とされており，モックアップによる測定結果，複数機関によるベンチマー ク解析の結果から決定されている．SCC の発生する内表面で $50 \mathrm{MPa}$ ，外表面では $350 \mathrm{MPa}$ となる．式（2）は国

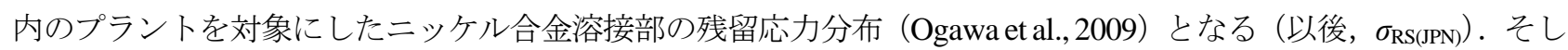
て, 式（3）は参照のために設定した一様応力分布となる (以後, $\sigma_{\mathrm{RS}(\mathrm{UNI})}$ ). 解析では, 残留応力に内圧 $P_{\mathrm{i}}$ と, 内 圧による Hoop 応力を考慮した．具体的には，内径 $D_{\mathrm{i}}=700 \mathrm{~mm}$ ，厚さ $70 \mathrm{~mm}$ の配管を想定した Hoop 応力 $P_{\mathrm{i}} \times$ $D_{\mathrm{i}} /(2 t)$ と内圧の和に相当する $6 P_{\mathrm{i}}$ の圧力を亀裂面一付与寸ることになる. 内圧をおおよそ $15.4 \mathrm{MPa}$ として， $\left(\sigma_{\mathrm{RS}}+\right.$ 100） MPa を亀裂面に付与して K 值を算出した.

亀裂進展速度 $d a / d t$ は，維持規格の事例規格（ニッケル合金の PWR 一次系水質環境中の SCC 亀裂進展速度）

（日本機械学会，2010）において, ニッケル合金（600 合金）溶接金属の亀裂進展速度として規定されている次 式を適用した.

$$
\frac{d a}{d t}=1.70 \times 10^{-14} K^{2.42}
$$

単位は $d a / d t か ゙[\mathrm{~m} / \mathrm{s}] ， K$ が[MPa m $\left.{ }^{0.5}\right]$ となる。この式は，国産材（132 合金および 82 合金）を用いて，試験条件， 試験方法を実機条件に合わせて取得された試験データ（原子力安全基盤機構, 2006）を基に策定された. 実験デー タの上限ではなく, 平均値が採用されている.

\section{$2 \cdot 3$ 亀裂進展方法}

亀裂進展方法としては，表 1 に示した 3 つの進展手順（進展モード）を考慮した．これらのモードに従った進 展方法を図 5 に模式的に示した．RECT-CRACK ではモード 2 のみが対象となる．モード 1 は FE-CRACK の本来 の機能を活用した方法で, 亀裂前縁の各節点で算出された $\mathrm{K}$ 值にしたがって亀裂形状を変化させながら進展を模 擬する. 本報では，この方法による進展が実機を模擬していると考え，基本モードと位置づける．モード 2 とモ ード 3 では維持規格と同様に, 表面点と最深点（矩形亀裂の場合は中央点）の 2 点の $\mathrm{K}$ 值のみを用いて進展を予 測する. したがって，モード 2 とモード 3 では亀裂形状は，半楕円形状または矩形形状に限定される．モード 3 ではさらに，アスペクト比が 1 を超えないという制限を設ける。 したがって，モード 3 が維持規格に従った進展 予測方法となる. これらの進展方法に加え, 表面方向に亀裂長さの制限 $L_{\mathrm{x}}$ を設定した場合も想定寸る. これは, 図 1 においてニッケル合金溶接金属に発生・進展した亀裂が低合金鋼，またはステンレス鋼との境界で停留する ことを模擬している．つまり， $L_{\mathrm{x}}$ は溶接金属幅の 2 分の 1 に相当し， $L_{\mathrm{x}}=10 \mathrm{~mm}$ または $20 \mathrm{~mm}$ とした. 
初期の亀裂深さは $a=7 \mathrm{~mm}(a / t=0.1)$, 表面長さは $c=7 \mathrm{~mm}$ とした. 一様荷重下でアスペクト比がおおよそ 0.9 になることから (Kamaya, 2008), 初期のアスペクト比を $a / c=1$ とした. 時間 $t_{\mathrm{m}}$ あたりの各節点での亀裂進展量 $\Delta a$ は次式で算出した.

$$
\Delta a=\frac{d a}{d t} \times t_{\mathrm{m}}
$$

時間 $t_{\mathrm{m}}$ は, 最深点（中央点）における $\Delta a$ が $0.01 a$ となるように決定した. $\Delta a$ は前縁上の各節点における $\mathrm{K}$ 值に 応じて算出されるが，その亀裂進展方向は，亀裂前縁各点の法線方向とする.

亀裂梁さが板厚の $80 \%$ を超えた時点で解析を終了した。 この手順に従うと, 進展解析終了までに, K 值をおお よそ 207 回計算することになる.

Table 1 Growth procedures considered in crack growth simulation suing FE-CRACK and RECT-CRACK.

\begin{tabular}{l|l}
\hline Mode & Procedure \\
\hline $\begin{array}{l}\text { Mode } 1 \\
\text { (Basic Mode) }\end{array}$ & $\begin{array}{l}\text { Crack shape is altered using growth rate calculated at each node along } \\
\text { the crack front (for simulating actual growth behavior) }\end{array}$ \\
\hline $\begin{array}{l}\text { Mode } 2 \\
\text { (Follows FFS code, allows } a / c>1)\end{array}$ & $\begin{array}{l}\text { Crack growth is calculated at the surface and deepest points and crack } \\
\text { keeps semi-elliptical or semi-circular shape. }\end{array}$ \\
\hline $\begin{array}{l}\text { Mode } 3 \\
\text { (Follows FFS code, not allow } a / c>1)\end{array}$ & $\begin{array}{l}\text { The same as Mode } 2 \text { although crack shape is not allowed to be } a / c>1 . \\
\text { The crack shape is replaced with semi-circular one when } a / c>1 . \text { This } \\
\text { procedure is the same as that prescribed in JSME FFS code. }\end{array}$ \\
\hline
\end{tabular}

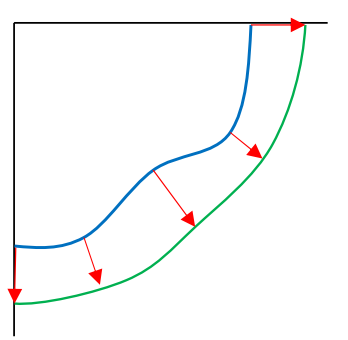

Mode 1 (Arbitrary shape)

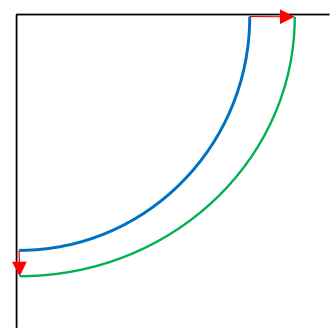

Mode 2

(Semi-elliptical)

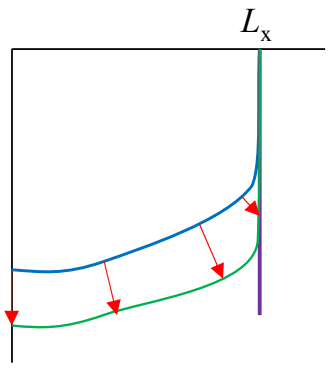

Mode $1\left(L_{\mathrm{x}}>0\right)$

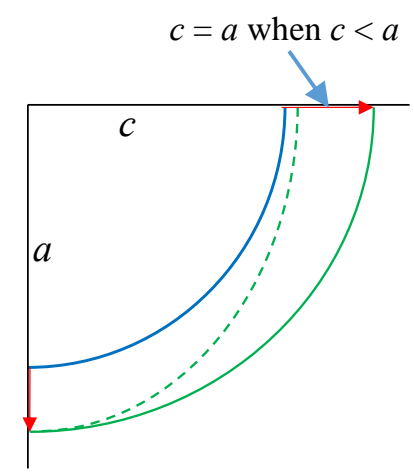

Mode 3

(Semi-elliptical, $a / c \leq 1$ )

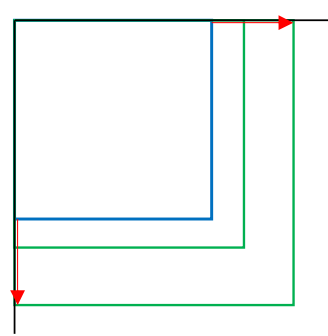

Mode 2

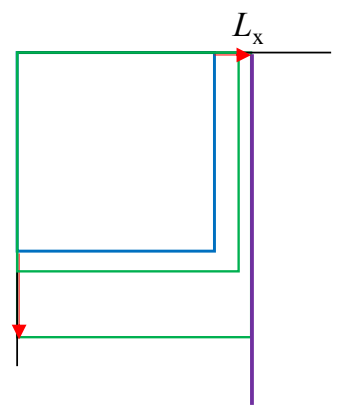

Mode $2\left(L_{\mathrm{x}}>0\right)$

(b)For RECT-CRACK

(a)For FE-CRACK

Fig. 5 Crack growth modes assumed in crack growth simulations. Table 1 describes the details of each mode. 


\section{3. 解析結果 (FE-CRACK)}

\section{$3 \cdot 1$ 基本モード（モード 1）による進展解析}

基本となるモード 1 による解析結果を図 6 に示す. 残留応力が $\sigma_{\mathrm{RS}(\mathrm{ASME})}$ の場合, 半円形状の初期亀裂は深さ方 向に相対的に速い進展となり, 縦長の（アスペクト比が 1 以上の）亀裂に成長した. この変化は, 深くなるほど 大きくなる残留応力分布に対応している，モード1では，任意の亀裂形状を許容するが，得られた亀裂形状は半 楕円に近い形状となった. 残留応力が $\sigma_{\mathrm{RS}(\mathrm{PP})}$ の場合は, 深さ方向よりも表面方向への進展が顕著であった. 形状 も, 残留応力分布の複雑な変化に対応して変化している. 一様な残留応力 $\sigma_{\mathrm{RS}(\mathrm{UNI} I)}$ の場合, 亀裂はほぼ半楕円形状 を維持しながら進展した。

\section{$3 \cdot 2$ 維持規格の手順による解析（モード 2 およびモード 3）}

表面点と最深点の $\mathrm{K}$ 值から，表面方向と長さ方向の進展のみを計算するモード 2 ，および，その際のアスペク ト比が 1 を超えないように制限寸るモード 3 の計算結果を図 7 に示寸。これらの進展モードでは, 亀裂形状は半
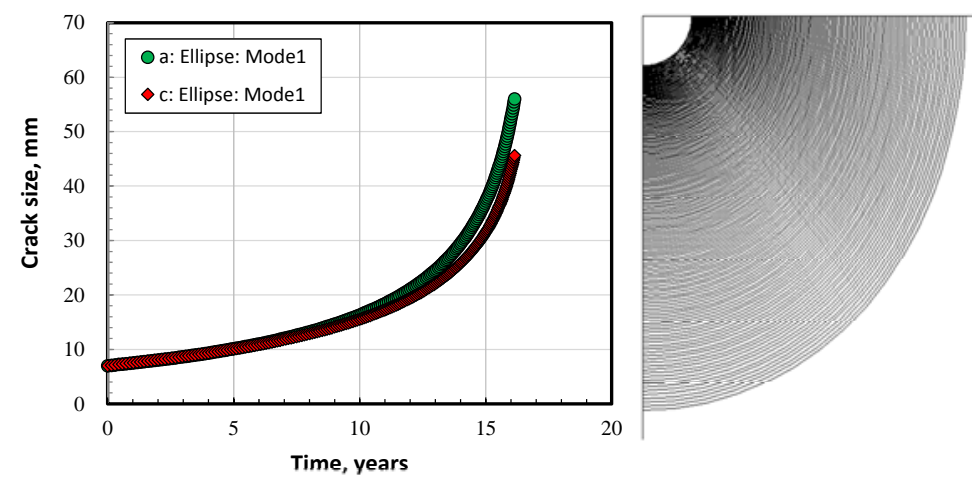

(a)Residual stress: $\sigma_{\mathrm{RS}}(\mathrm{ASME})$
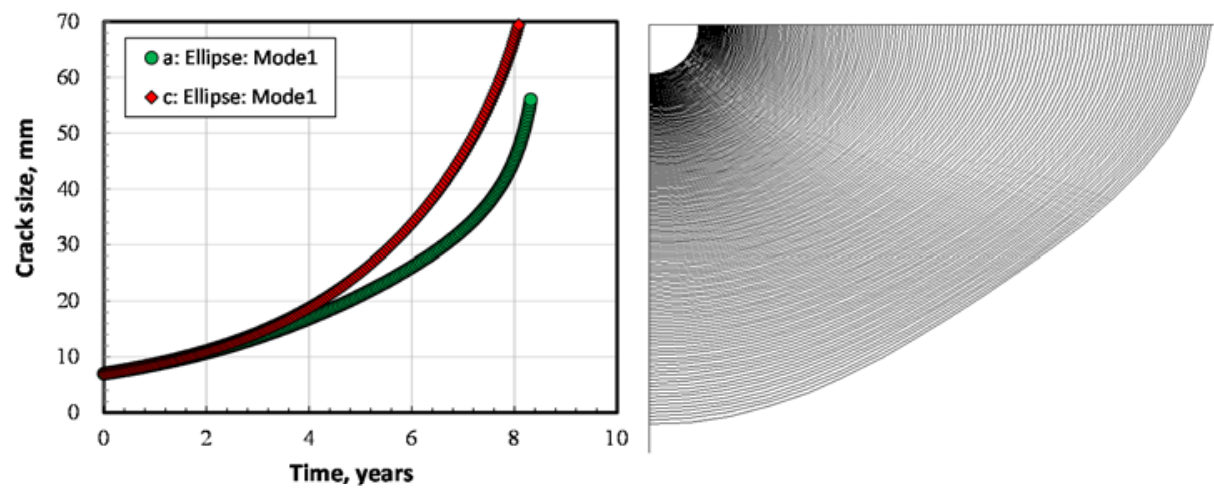

(b)Residual stress: $\sigma \mathrm{RS}(\mathrm{JPN})$
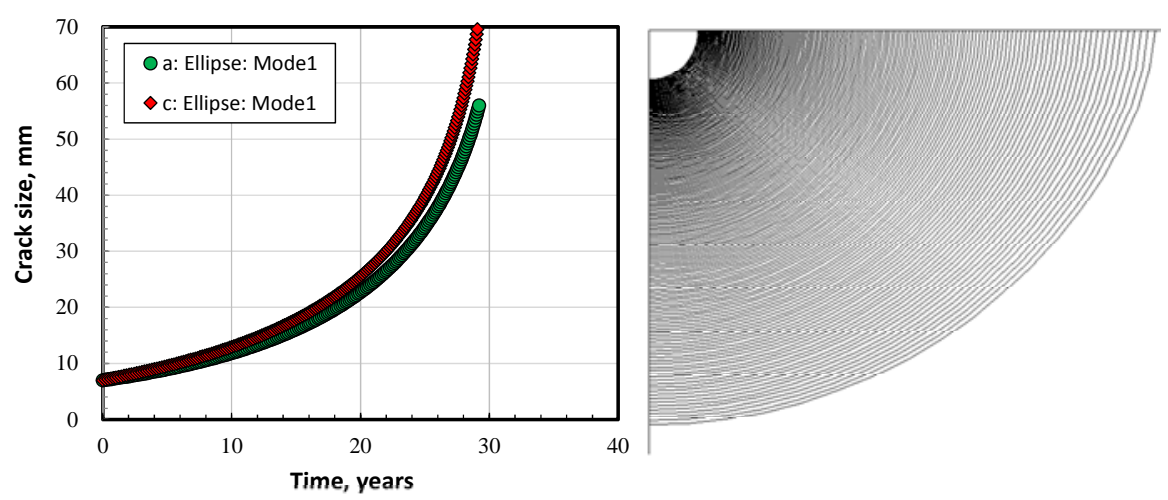

(c)Residual stress: $\sigma_{\mathrm{RS}(\mathrm{UNI})}$

Fig. 6 Crack growth simulation results conducted for Mode 1.

The growth behavior depended on the residual stress distribution. 


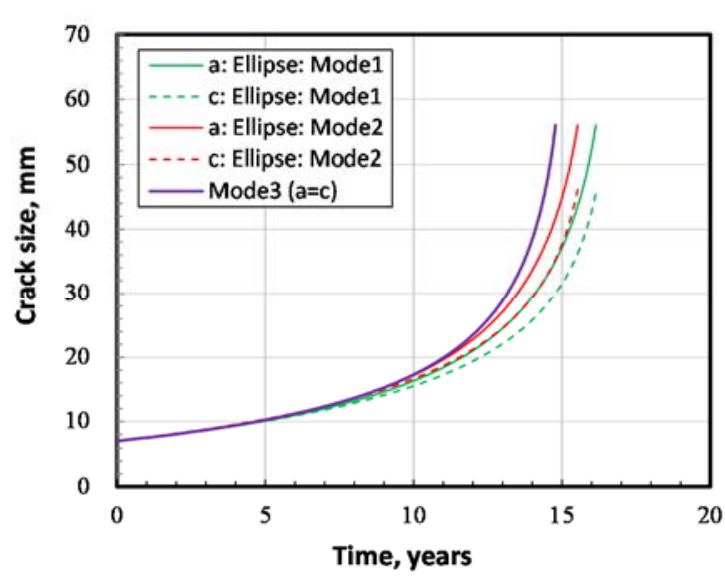

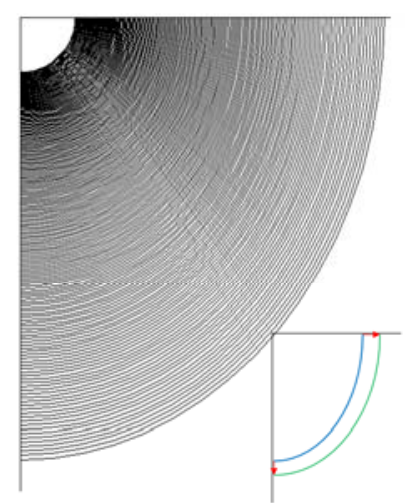

Mode 2

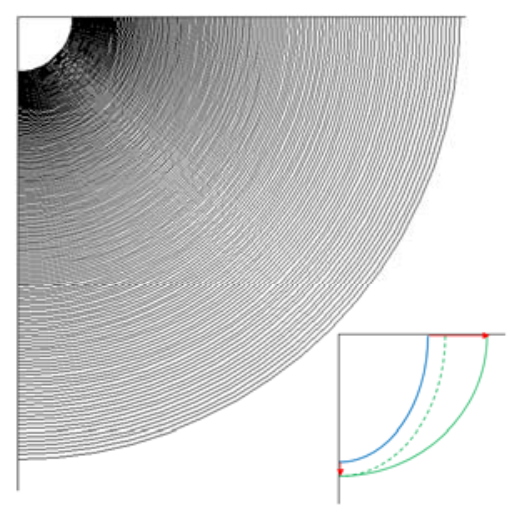

Mode 3

(a)Residual stress: $\sigma_{\text {RS(ASME) }}$

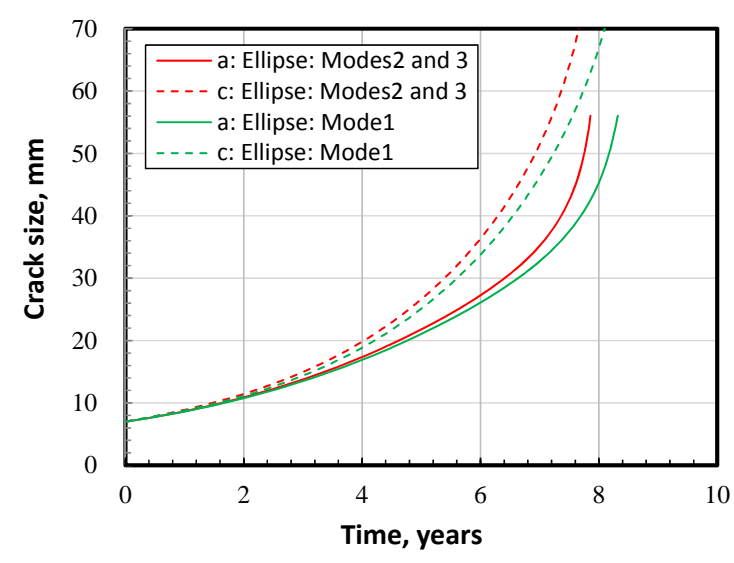

(b)Residual stress: $\sigma_{\mathrm{RS}(\mathrm{JPN})}$

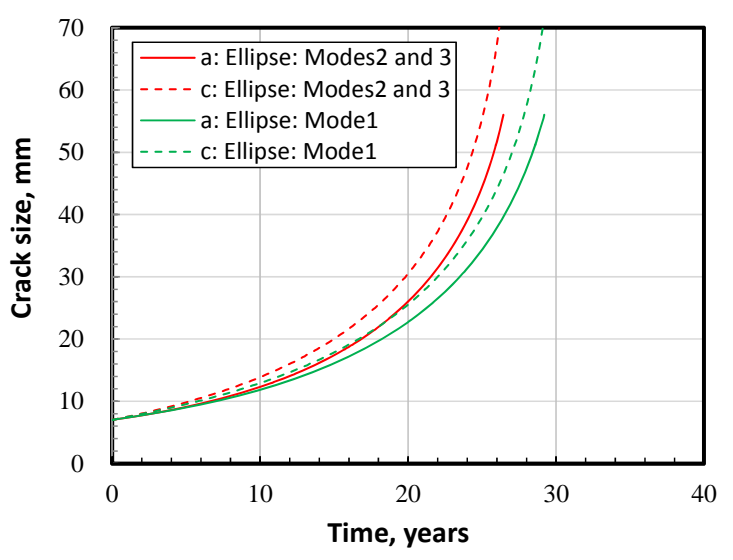

(c)Residual stress: $\sigma_{\mathrm{RS}(\mathrm{UNI})}$

Fig. 7 Crack growth simulation results conducted for Modes 2 and 3. The cracks kept semi-elliptical in shape. The results of Modes 2 and 3 were the same for the residual stress $\sigma_{\mathrm{RS}(\mathrm{JPN})}$ and $\sigma_{\mathrm{RS}(\mathrm{UNI}) \text {. }}$

楕円形状を維持する．比較のため，モード 1 の結果を併せて示すが，残留応力が $\sigma_{\mathrm{RS}(\mathrm{ASME})}$ の場合，モード 2 の結 果はモード 1 とほぼ一致した。一方, 残留応力が $\sigma_{\mathrm{RS}(\mathrm{PN})}$ または $\sigma_{\mathrm{RS}(\mathrm{UNI})}$ の場合は, モード 2 が安全側の予測となっ た. モード 1 が実際の進展を模擬していると考えると，モード 2 の進展予測は実際に近く，かつ，安全側の予測 となっている.つまり, 表面点と最深点の 2 点の $\mathrm{K}$ 值を用いる維持規格の進展予測方法の妥当性を裏付ける結果 となった.

モード 3 では, アスペクト比が 1 を超えないように制限しているが, 残留応力が $\sigma_{\mathrm{RS}(\mathrm{PN})}$ と $\sigma_{\mathrm{RS}(\mathrm{UNI})}$ の場合は，モ ード 2 の場合でもアスペクト比が 1 を越えなかったので, モード 2 とモード 3 の結果は一致した。 $\sigma_{\mathrm{RS}(\mathrm{ASME})}$ の場 合は，亀裂は初期の半円形状を維持したまま進展している，そして，その進展速度はモード 1 の場合に比べて速 い. 一般的に，亀裂面積が大きくなるほど $\mathrm{K}$ 值は大きくなる. アスペクト比を 1 以下とするためには, 表面方向 に予測值以上の進展を仮定することになり，亀裂面積はモード 2 の場合よりも大きくなる．したがって，モード 3 は，モード 1 およびモード 2 よりも速い進展となった. 現在の維持規格では，アスペクト比が 1 を超えること を許容していないが，1 以上のアスペクト比を許容することで合理的な進展予測が可能となる.

\section{$3 \cdot 3$ 亀裂長さ制限 $L_{x}$ の影響}

残留応力 $\sigma_{\mathrm{RS}(\mathrm{ASME})}$ に対して亀裂の長さを最大 $L_{\mathrm{x}}$ に制限したモード 1 の結果を図 8 に示す. 亀裂の表面長さが最 大 $L_{\mathrm{x}}$ で制限されている様子が再現されている. 結果として, 亀裂は深さ方向に進展し, 板厚の $80 \%$ に到達した. この進展は，亀裂が溶接金属を進展し，母材部で亀裂進展が停留することを模擬している． $L_{\mathrm{x}}$ にる制限を仮定 


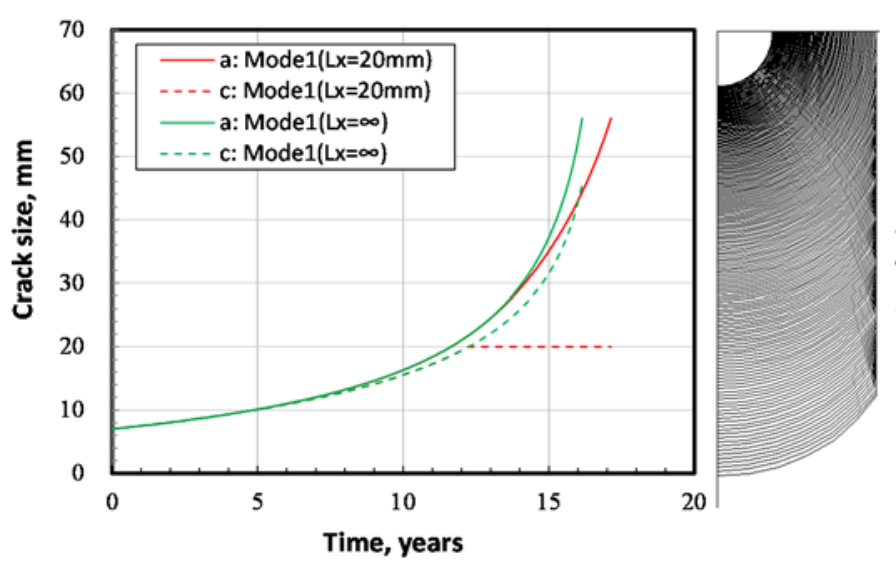

(a) $L_{\mathrm{x}}=20 \mathrm{~mm}$

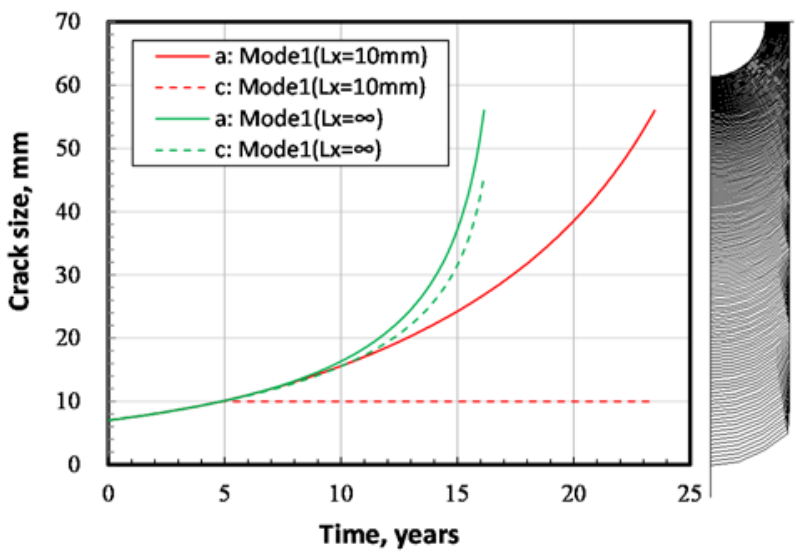

(b) $L_{\mathrm{x}}=10 \mathrm{~mm}$

Fig. 8 Crack growth simulation according to Mode 1 considering limitation in growth in the surface direction. The surface length can be larger than $L_{\mathrm{x}}$. Residual stresses of $\sigma \mathrm{RS}(\mathrm{ASME})$ was applied.

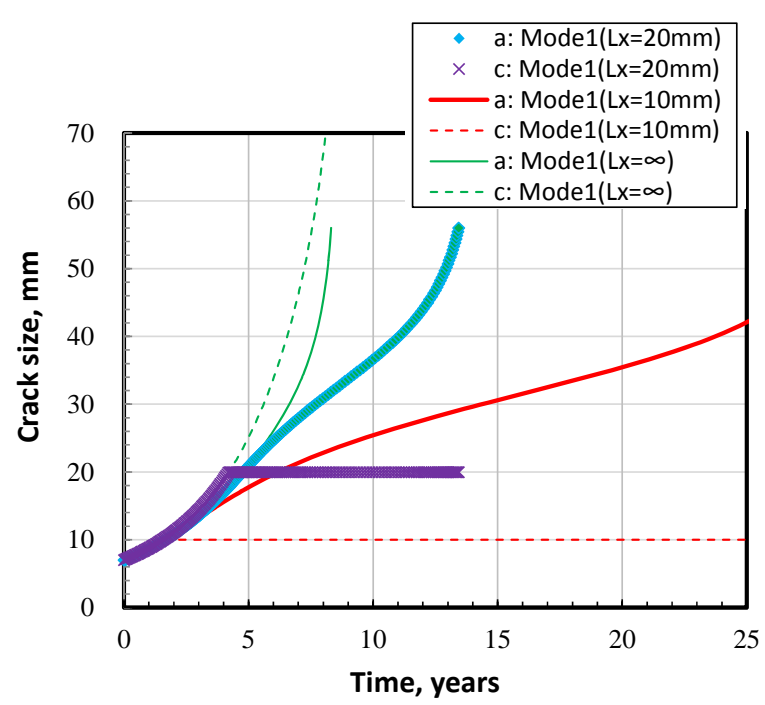

(a) Residual stress: $\sigma_{\mathrm{RS}(\mathrm{JPN})}$

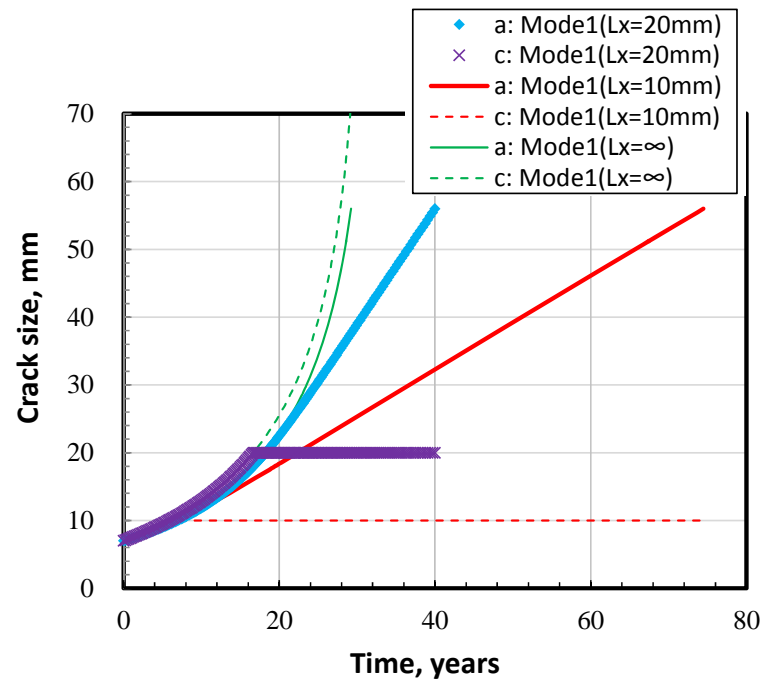

(b) Residual stress: oRS(UNI)

Fig. 9 Crack growth simulation according to Mode 1 with limitation of growth in the surface direction $L_{\mathrm{x}}$. Residual stresses of $\sigma \mathrm{RS}(\mathrm{JPN})$ or $\sigma \mathrm{RS}(\mathrm{UNI})$ was applied.

することで，制限のない場合（図中で “ $L_{\mathrm{x}}=\infty ”$ と表示）の進展よりも遅くなった．つまり，実機において亀裂 進展が停留寸ると，深さ方向の進展が遅くなると考えられる．そして，その進展は， $L_{\mathrm{x}}$ の制限のないモード 1 に よって安全に予測できる， $L_{\mathrm{x}}$ が小さくなるほど，進展が遅くなっている．これは， $L_{\mathrm{x}}$ による制限のため亀裂面の 面積が小さくなるためと考えられる. 図 9 に示寸ように, 残留応力が $\sigma_{\mathrm{RS}(\mathrm{PPN})}$ と $\sigma_{\mathrm{RS}(\mathrm{UNI})}$ の場合も同様の結果が得ら れた.つまり, 進展に対して溶接境界で進展が停留する場合でも, 現状の維持規格の手順にしたがえば安全側の 進展予測ができる.

維持規格では亀裂形状は半楕円形状としてモデル化される. モード 2 の解析において $L_{\mathrm{x}}=20 \mathrm{~mm}$ とした場合, 図 10 に示寸ように，亀裂は半楕円形状を維持しながら進展することになる．表面長さが $L_{\mathrm{x}}$ に到達した時点で表 面方向の進展は停止し，半楕円形状を維持しながら，深さ方向にのみ進展する. $L_{\mathrm{x}}=20 \mathrm{~mm}$ としたモード 1 の結 果と比較すると，モード 2 の予測は危険側となっている。つまり，モード 1 の予測が実機を想定していると考え た場合, 溶接境界での亀裂の停留を考慮したモード 2 にる予測は, 危険側となる場合がある. 図は省略するが, $L_{\mathrm{x}}=10 \mathrm{~mm}$ とした解析におけるモード 1 とモード 2 差は, $L_{\mathrm{x}}=20 \mathrm{~mm}$ とした場合より大きくなった. 亀裂が母材 


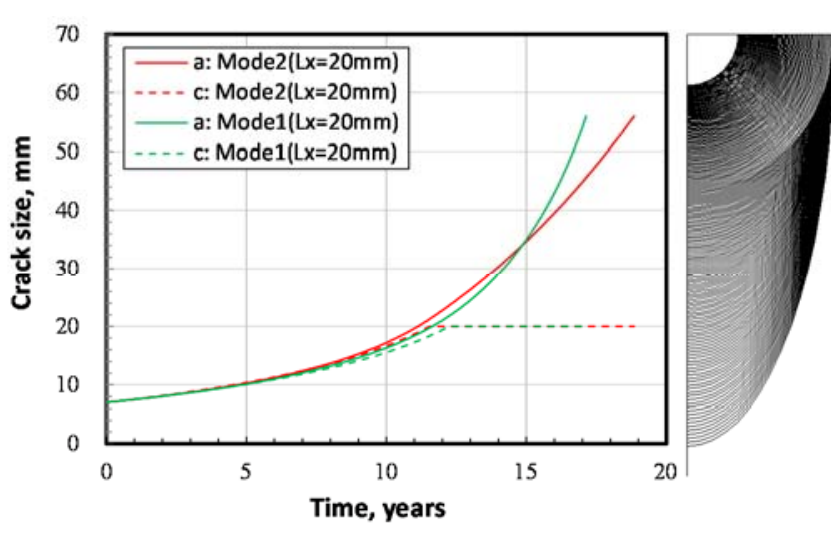

(a) Residual stress: $\sigma_{\mathrm{RS}(\mathrm{ASME})}$

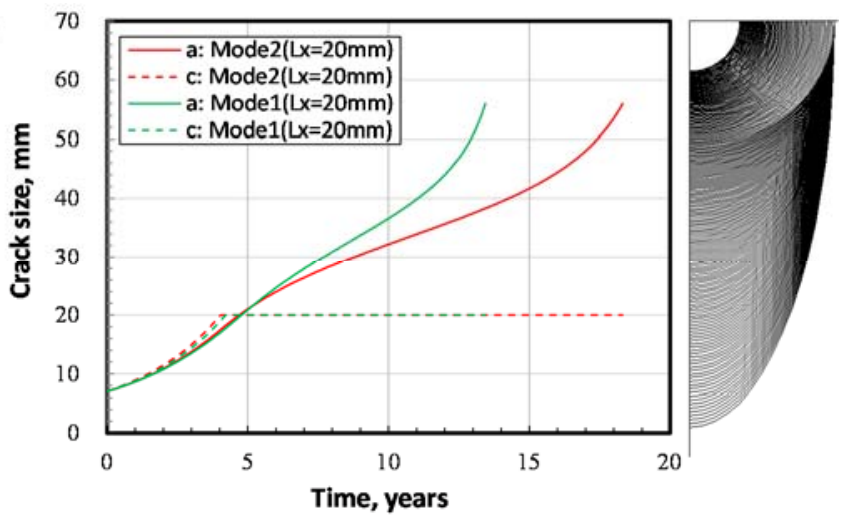

(b) Residual stress: $\sigma_{\mathrm{RS}(\mathrm{JPN})}$

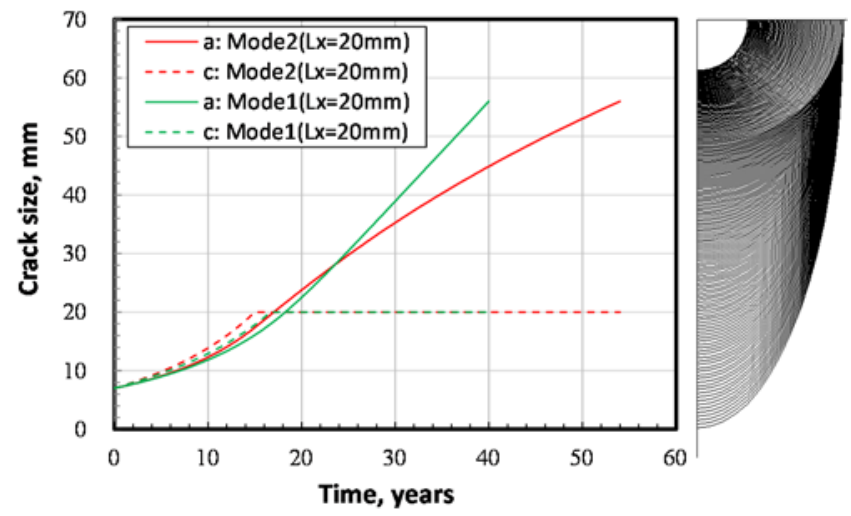

(c) Residual stress: $\sigma_{\mathrm{RS}(\mathrm{UNI})}$

Fig. 10 Crack growth simulation according to Mode 2 considering the limitation in the growth in the surface direction. The crack kept semi-elliptical shape and the surface length could not be larger than $L_{\mathrm{x}}$.

に進展しないと想定された場合でも，解析上は進展するとした $\left(L_{\mathrm{x}}\right.$ による制限を設定しない) 解析を実施する必 要がある.

\section{4. 解析結果 (RECT-CRACK)}

\section{$4 \cdot 1$ 残留応力 $\sigma_{\mathrm{RS} \text { (ASME) }}$ の場合の進展}

矩形亀裂の進展に関する基本的な特徵を考察するために, 残留応力が $\sigma_{\mathrm{RS}(\mathrm{ASME})}$ の場合の解析結果を図 11 に示 す．K 值は矩形形状の前縁に沿って算出されるが，進展計算には表面点と中央点における $\mathrm{K}$ 值を用いて，表面方 向と深さ方向の進展量を計算した. FE-CRACKによるモード 1 とモード 2 の結果も併せて示寸が，矩形亀裂でモ デル化した結果が，半楕円形状でモデル化した場合（モード2）より明らかに速いことがわかる．モード 1 と比 べると, 矩形でモデル化した場合の進展予測は, 安全側となった. 図には, アスペクト比 a/c の変化も示したが, 矩形でモデル化した場合のアスペクト比は, FE-CRACKよりも大きくなり, その変化は亀裂形状からも確認でき る.

$a=c=7 \mathrm{~mm}$ の半円と矩形形状の亀裂に対寸る解析で得られた前縁に沿った K 值の分布を図 12 に示す. 矩形亀 裂の $\mathrm{K}$ 值は同じ亀裂寸法の半円亀裂に比べて大きくなった．とくに，中央点での $\mathrm{K}$ 值の差が大きく, その差によ って, 深さ方向の進展が相対的に速くなり $a / c$ が大きくなったと考えられる. 一方，矩形のコーナ一部近傍では $\mathrm{K}$ 值が相対的に小さく, コーナー部では $\mathrm{K}$ 值が急減に減少する特異点となった. 


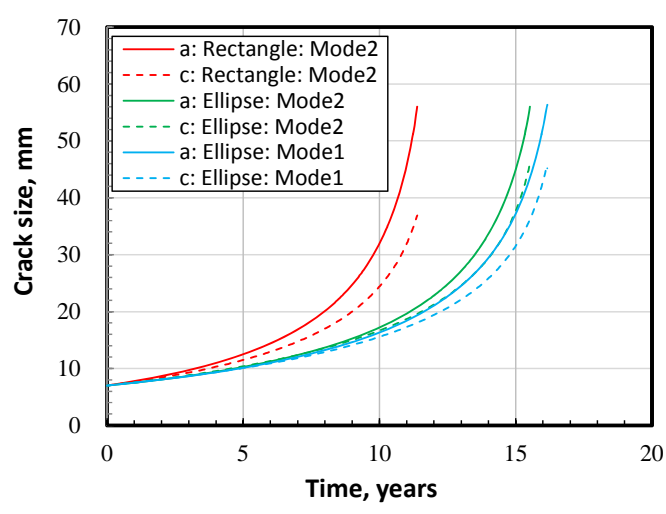

(a)Change in crack size

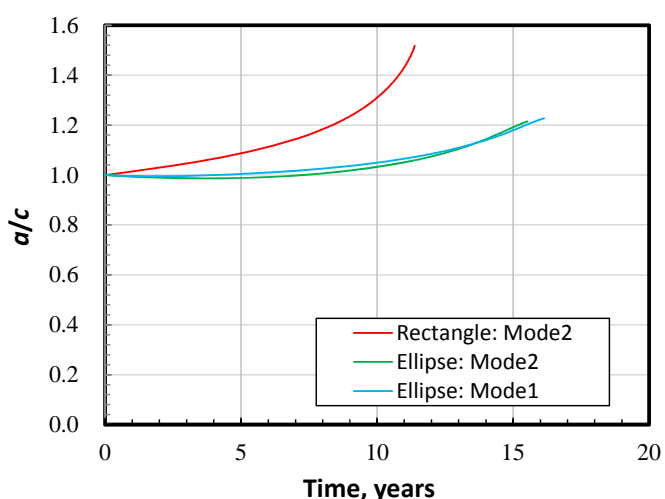

(b)Change in aspect ratio

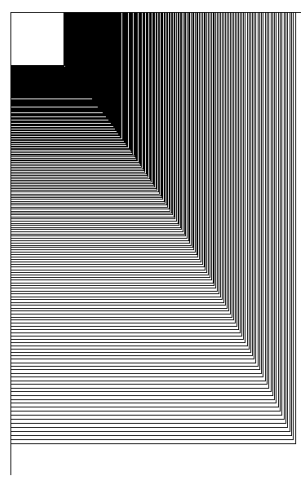

(c)Change in crack shape

Fig. 11 Crack growth simulation results obtained by RECT-CRACK code. The Mode 2 growth rule was applied for a surface crack of rectangular shape.
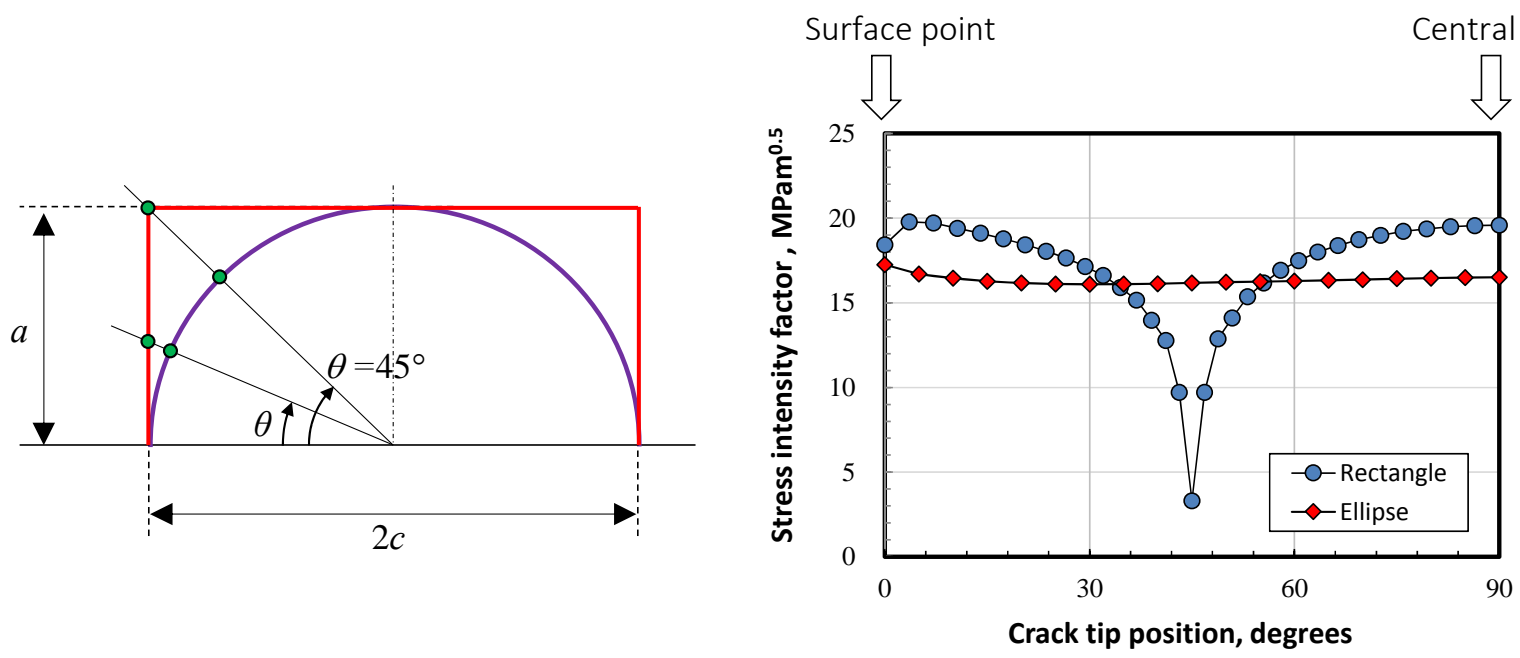

Fig. 12 Comparison of stress intensity factors along crack front for semi-circular and rectangle cracks. Calculations were conducted for $a=c=7 \mathrm{~mm}$ and $\sigma_{\mathrm{RS}}$ (ASME). The stress intensity factor of the rectangle crack was larger than that of semi-circular crack.

\section{$4 \cdot 2$ 亀裂長さ制限 $L_{\mathrm{x}}$ の影響}

FE-CRACK を用いて，表面方向に亀裂長さの制限 $L_{\mathrm{x}}$ を設定した場合の亀裂形状は，半棈円というよりはむし ろ, 矩形に近かった. また, 維持規格の進展評価方法に近いモード 2 にって, $L_{\mathrm{x}}$ を設定した場合の進展予測は, 実際の進展を模擬したモード 1 の進展を危険側に予測した。したがって，溶接部の進展を模擬する場合は，亀裂 を矩形でモデル化することが選択肢の一つとして考えられる．そこで， $L_{\mathrm{x}}$ を $10 \mathrm{~mm}$ とした場合に，矩形でモデル 化した亀裂の進展解析結果を図 13 に示寸，比較のために，FE-CRACK のモード 1 を用いて， $L_{\mathrm{x}}$ を設定した場合 の結果も示す.

いずれの残留応力に対しても，モード1の結果（実機を模擬した解析）よりも安全側の予測となっている.モ 一ド 1 の結果は矩形に近く，また，矩形亀裂の $\mathrm{K}$ 值は中央点で相対的に大きくなったことから，矩形亀裂による 進展解析（モード 2） は安全側の予測なったと考えられる. 図には $L_{\mathrm{x}}=10 \mathrm{~mm}$ の結果を示したが， $L_{\mathrm{x}}=20 \mathrm{~mm} の$ 場合は，矩形亀裂の進展予測がさらに安全側となった。 


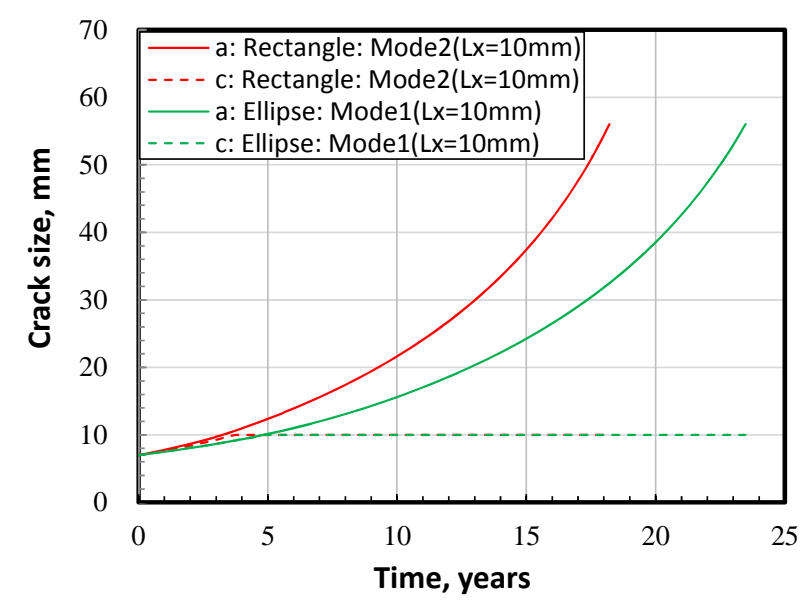

(a)Residual stress: $\sigma_{\mathrm{RS}(\mathrm{ASME})}$

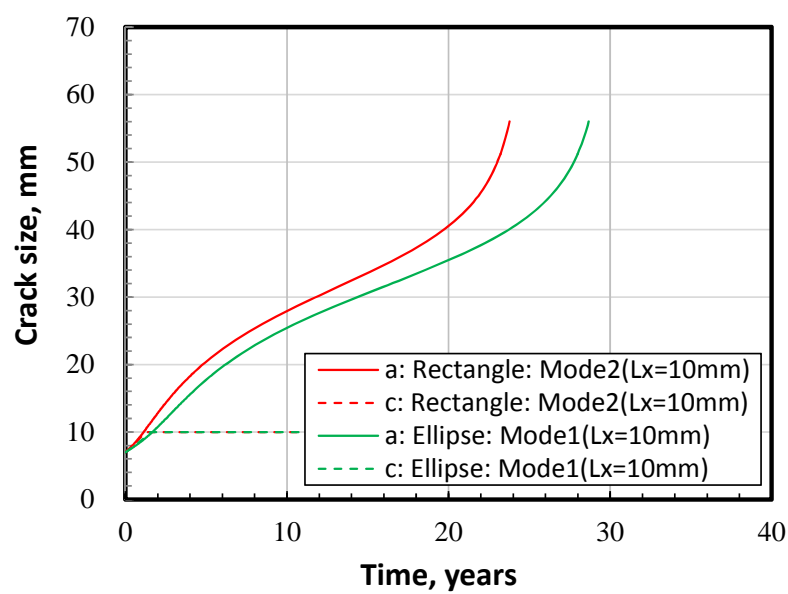

(b)Residual stress: $\sigma_{\mathrm{RS}(\mathrm{JPN})}$

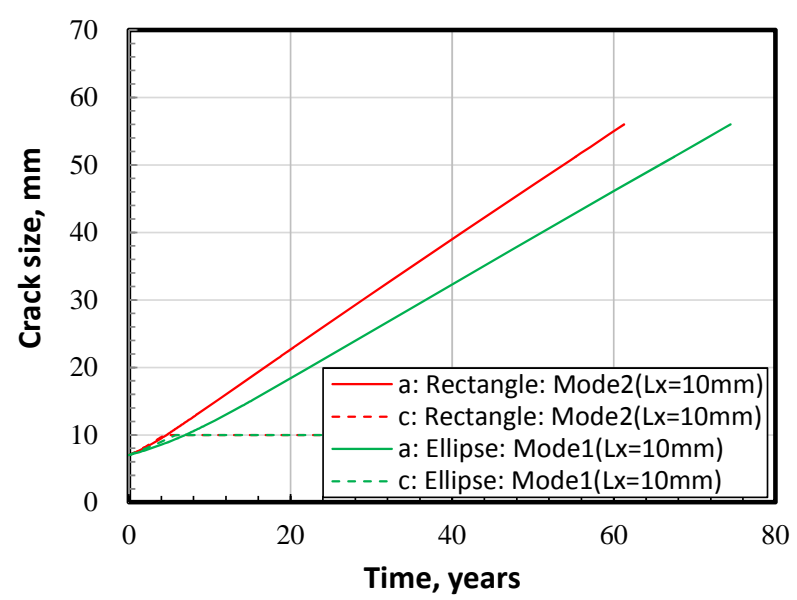

(c)Residual stress: $\sigma_{\mathrm{RS}(\mathrm{UN})}$

Fig. 13 Crack growth simulation obtained using RECT-CRACK code with limitation of growth in the surface direction.

\section{5. 考 察}

\section{$5 \cdot 1$ 亀裂を矩形でモデル化することの妥当性}

本報では，ニッケル合金の溶接金属に発生した SCC の進展予測を行うことを想定し，アスペクト比が 1 よりも 大きくなる場合，および亀裂進展が継手界面で停留する場合（ $L_{x}$ を設定する場合）を想定し，維持規格での進展 予測方法を検討した．とくに，半楕円でモデル化されている亀裂を，矩形形状でモデル化することの是非につい て考察した

半楕円形状で亀裂をモデル化した場合，アスペクト比が 1 より大きくなる場合でも，モード 2 の方法によって SCC の進展が妥当に予測できることが示された．一方，二ッケル合金に発生した SCC がステンレス鋼や低合金 鋼に進展しないことを解析上模擬する場合（ $L_{\mathrm{x}}$ を設定する場合）は，モード 2 の進展は危険側の予測になった. この対応として， $L_{\mathrm{x}}$ を設定する場合は矩形でモデル化することで, 実際の進展を模擬した解析（モード1で $L_{\mathrm{x}}$ を 設定した場合）を安全側に予測できた.

維持規格の評価を考えた場合，配管に発生した周方向の亀裂をモデル化する際も，矩形でモデル化する方法が 考えられる. 周方向亀裂では, 厳密な半楕円でのモデル化はできない. 対応方法として, 半楕円形状を円弧上に 写像変換する方法, または半楕円形状を配管断面に重祮合わせる方法の 2 通りが考えられるが，維持規格では， どちらの方法を選択するかは規定されていない. また, 亀裂が表面方向に進展し, アスペクト比が極端に小さく 


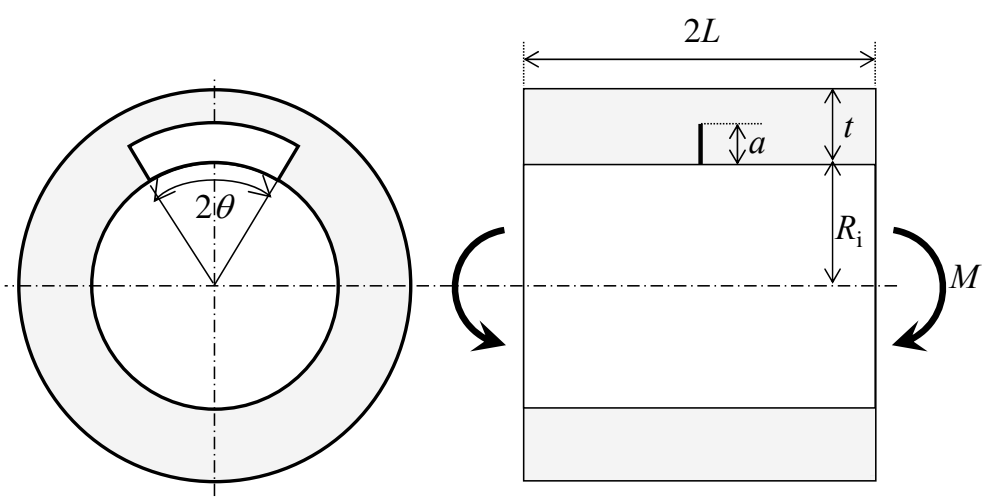

Fig. 14 Possible modeling procedure for a circumferential surface crack. The uniform crack depth is assumed.

なると, 表面近傍の亀裂形状は大きく歪むことになる.これに対し, 矩形亀裂は, 図 14 に示すように, 一定深さ の円周亀裂として一意に定義することができる．亀裂が表面方向に進展して，アスペクト比が小さくなる場合， その形状は, 半楕円よりも, 矩形 (一定深さの円周亀裂) でモデル化する方が妥当であるとの考え方もできる. さらに，維持規格において周方向亀裂の極限荷重を算出寸る際の亀裂形状は，矩形形状を想定している. 進展評 価と破壊評価の一貫性の観点からも，矩形形状でモデル化することを許容することも選択肢の一つとして考えら れる.

\section{$5 \cdot 2$ 進展予測において考慮すべき事項}

本報では，FE-CRACKによるモード1の予測が実際の進展挙動である（または，それに近い）として，各種の 解析結果を比較・検討してきた. しかし, 実際の亀裂進展が必ずしもモード 1 で模擬できるとは限らない. FECRACKによるモード1の解析で考慮できていない事項として以下が挙げられる.

(1)材料変形特性（ヤング率など）の材料毎の違い（界面で不整合応力が発生する可能性がある）

(2)進展速度の異方性（組織に沿った深さ方向の進展が，表面方向よりも速い可能性がある）

(3)亀裂は 2 次元平面内を進展すると仮定しているが，実際には面外に進展する可能性もある.

(4)実際の亀裂進展は配管軸方向に進展することが想定されるが，解析では全て平板内を進展すると仮定した.

そもそも，亀裂進展速度や残留応力にはばらつきが存在することから，実際の進展を予測するという観点から は, 予測誤差はさらに大きくなる可能性がある. 維持規格では, 実用的に適用可能で, 工学的に妥当と判断でき る方法として, 現在の手順が規定されている. そこでは, 亀裂進展速度が $\mathrm{K}$ 值によって予測できることが前提と なっている．本報のモード 1 の解析では，K 值にしたがって，材料特性の不均一分布や速度の異方性を考慮せず に, 亀裂を同一平面状に進展させるという維持規格と同じ考え方で, 進展を模擬した，維持規格の考え方が妥当 とする前提では，モード I を基本モードと位置づけることは問題ないと考えられる. しかし，本解析を踏まえた 進展予測手順の検討においては, 上記の(1)から(4)に加え想定する亀裂進展速度や残留応力の妥当性についても留 意する必要がある.

\section{6. 結 言}

任意の亀裂形状に対して K 值を算出する機能を有する FE-CRACK と矩形亀裂を対象に進展解析が実施できる RECT-CRACK を用いて, 残留応力下での亀裂進展を模擬した. 種々の条件の解析結果から, 進展予測手順の検討 を行った. その結果，以下の結論を得ることができた。

（1）現在の維持規格で規定されている $a / c \leqq 1$ でモデル化するという制約は, 残留応力下での亀裂進展を予測 する段階では，撤廃しても問題ないことを確認した。 
（2）異材界面などで進展が制限される場合でも，表面方向の進展に制限がないと仮定して進展を予測すること で，評価上は安全側の予測ができる.

（3）逆に，進展の制限があると仮定して，半楕円の亀裂進展を予測した場合（ $L_{\mathrm{x}}$ を設定したモード 2 にる予 測）は，実際の進展（モード1による解析）を危険側に予測する可能性がある.

（4）亀裂形状を半楕円ではなく矩形でモデル化しても, 時間に対する亀裂深さの変化は安全側に予測できる.

（5）表面方向の進展が制限される場合（ $L_{\mathrm{x}}$ を設定する場合）を想定して進展予測を安全側に行うためには，亀 裂形状は半楕円でなく，矩形でモデル化する方がよい.

\section{文献}

Broussard, J. E., Standard through-wall distributions of dissimilar metal weld residual stress, Proceedings of ASME Pressure Vessels and Piping Division Conference (2015), paper no.45950.

原子力安全基盤機構, 平成 17 年度 $\mathrm{Ni}$ 基合金応力腐食割れ(SCC)進展評価技術調査(定荷重試験)に関寸る報告書, 06 基材報-0012, 平成 18 年 7 月(2006).

Kamaya, M., Stress intensity factors of surface crack with undulated front, JSME International Journal Series A Solid Mechanics and Material Engineering, Vol.49 (2006), pp.529-535.

Kamaya, M., Growth evaluation of multiple interacting surface cracks (part I: experiments and simulation of coalesced crack), Engineering Fracture Mechanics, Vol.75 (2008), pp.1336-1349.

Kamaya, M., J-integral solutions for surface crack inside pipe under bending load, Journal of Solid Mechanics and Materials Engineering, Vol. 3 (2009), pp.1115-1126.

Ogawa, N., Muroya, I., Iwamoto, Y., Hojo, K., Ogawa, K., Kingston, E. and Smith, D. J., Residual stress evaluation of dissimilar weld joint using reactor vessel outlet nozzle mock-up model (Report-2), Proceedings of ASME Pressure Vessels and Piping Division Conference (2009), paper no.77269.

日本機械学会, 発電用原子力設備規格維持規格, JSME S NA1-2016 (2016).

日本機械学会, 発電用原子力設備規格 維持規格 事例規格（ニッケル合金の PWR一次系水質環境中の SCC き裂 進展速度）, JSME NA-CC-006 (2010).

\section{References}

Broussard, J. E., Standard through-wall distributions of dissimilar metal weld residual stress, Proceedings of ASME Pressure Vessels and Piping Division Conference (2015), paper no.45950.

Japan Nuclear Energy Safety Organization, FY2005Rport for stress corrosion crack growth rate tests (constant load tests) of Nickel based alloy, 06-kizaiho-0012 (2006) (in Japanese).

Kamaya, M., Stress intensity factors of surface crack with undulated front, JSME International Journal Series A Solid Mechanics and Material Engineering, Vol.49 (2006), pp.529-535.

Kamaya, M., Growth evaluation of multiple interacting surface cracks (part I: experiments and simulation of coalesced crack), Engineering Fracture Mechanics, Vol.75 (2008), pp.1336-1349.

Kamaya, M., J-integral solutions for surface crack inside pipe under bending load, Journal of Solid Mechanics and Materials Engineering, Vol. 3 (2009), pp.1115-1126.

Ogawa, N., Muroya, I., Iwamoto, Y., Hojo, K., Ogawa, K., Kingston, E. and Smith, D. J., Residual stress evaluation of dissimilar weld joint using reactor vessel outlet nozzle mock-up model (Report-2), Proceedings of ASME Pressure Vessels and Piping Division Conference (2009), paper no.77269.

The Japan Society of Mechanical Engineers ed., Codes for nuclear power generation facilities: rules on fitness-for-service for nuclear power plants JSME S NA1-2016 (2016) (in Japanese).

The Japan Society of Mechanical Engineers ed., Codes for nuclear power generation facilities: code case for crack growth rate of stress corrosion cracking of Nickel alloy in PWR primary water environment, JSME NA-CC-006 (2010) (in Japanese). 